\begin{tabular}{c} 
Jurnal Inovasi Pembelajaran Fisika \\
(INPAFI) \\
$\begin{array}{c}\text { Available online http://jurnal.unimed.ac.id/2012/index.php/inpafi } \\
\text { e-issn 2549-8258, p-issn } 2337-4624\end{array}$ \\
\hline
\end{tabular}

\title{
MENINGKATKANHASIL BELAJARSISWADENGANMETODEDEMONSTRASI
}

\author{
Frikson Jony Purba \\ Fakultas Keguruan dan Ilmu Pendidikan Universitas Quality \\ purbafrikson@gmail.com \\ Diterima: Juni 2018; Disetujui: Juli 2018; Dipublikasikan: Agustus 2018
}

\begin{abstract}
ABSTRAK
Penelitian ini bertujuan untuk mengetahui peningkatan hasil belajar siswa setelah menggunakan metode demonstrasi pada mata pelajaran IPA di kelas IV. Penelitian dilaksanakan di SD Negeri 173229 Parinsoran Kecamatan Garoga. Subjek penelitian adalah seluruh siswa kelas IV yang berjumlah 24 siswa yang terdiri dari 8 siswa perempuan dan 16 siswa laki-laki. Objek penelitian adalah penggunaan metode demonstrasi untuk meningkatkan hasil belajar siswa. Teknik pengumpulan data adalah lembar observasi dan tes berbentuk essay yang dibatasi ranah kognitif $\mathrm{C} 1$ dan $\mathrm{C} 2$. Analisis data yang digunakan adalah rumus pelaksanaan pembelajaran, hasil belajar individual, ketuntasan klasikal, dan rata-rata hasil belajar siswa. Berdasarkan hasil analisis data diperoleh bahwa hasil penelitian siklus I dan siklus II terjadi peningktan $16,33 \%$ dari nilai $60 \%$ menjadi $70,1 \%$, aktivitas siswa meningkat 25\% dari nilai 64 menjadi 84 secara klasikal meningkat 31,25\% dari nilai 70,33\% menjadi $87,50 \%$ yang tuntas, dan rata-rata meningkat $9,63 \%$ dari nilai 69,75 menjadi 76,625 . Berdasarkan hasil analisis data disimpulkan bahwa (1) pelaksanaan pembelajaran berkategori baik, (2) hasil belajar siswa meningkat setelah menggunakan metode demonstrasi.
\end{abstract}

Kata Kunci: Hasil Belajar, Metode Demonstrasi

\section{PENDAHULUAN}

Pendidikan merupakan suatu proses pengembangan diri individu dari kepribadian seseorang yang dilakukan secara sadar dan penuh tanggung jawab untuk dapat meningkatkan pengetahuan, keterampilan, dan sikap sehingga mampu menyesuaikan diri dengan lingkungannya. Tujuan pendidikan itu pada hakikatnya memanusiakan manusia, atau mengantarkan anak didik untuk dapat menemukan jati dirinya. Adapun manfaat pendidikan adalah sebagai sarana untuk menumbuhkan semangat kebangsaan dan nasionalisme melalui dunia pendidikan dan menciptakan laboratorium pendidikan sebagai sarana pembelajaran dan penelitian bagi siswa dan masyarakat untuk memperhatikan dan berkreasi dalam upaya meningkatkan kualitas pendidikan.

Sagala (2013:4) menyatakan bahwa "Pendidikan adalah proses dalam rangka mempengaruhi siswa supaya mampu menyesuaikan diri dengan lingkungannya dan akan menimbulkan perubahan pada dirinya yang memungkinkan sehingga berfungsi sesuai kompetensinya dalam kehidupan masyarakat dan usaha sadar yang dilakukan seseorang, masyarakat dan pemerintah melalui kegiatan bimbingan, keterampilan dan sikap". Proses pendidikan umumnya dilaksanakan disekolah, dengan menggunakan Guru sebagai pendidik dan murid sebagai peserta didik. Pendidikan di sekolah mengajarkan beberapa mata pelajaran yaitu diantaranya mata pelajaran IPA. IPA 
adalah pengetahuan khusus dengan melakukan observasi, eksperimentasi penyimpulan penyusunan teori dan demikian seterusnya kait mengkait antara cara yang satu dengan cara yang lain, agar siswa mempunyai pengetahuan, gagasan dan konsep yang terorganisasi tentang alam sekitar, yang diperoleh dari pengalaman melalui serangkaian proses ilmiah antara lain penyelidikan, penyusunan dan penyajian gagasan-gagasan. Adapun tujuan IPA untuk menanamkan pengetahuan dan konsep-konsep IPA yang bermanfaat dalam kehidupan seharihari, mengembangkan keterampilan proses untuk menyelidiki alam sekitar, memecahkan masalah, dan membuat keputusan. Berdasarkan tujuan tersebut dapat disimpulkan bahwa pemberian pendidikan IPA bertujuan agar siswa mampu menguasai konsep IPA dan keterkaitanya serta mampu memelihara, menjaga, dan melestarikan lingkungan alam.

Informasi yang diberikan oleh kepala sekolah dan guru wali kelas yang mengajar di Negeri 173229 Parinsoran Kecamatan Garoga, pembelajaran IPA di kelas IV SD ini menemukan banyak permasalahan yang terkait dengan pembelajaran IPA. Terbukti dari hasil belajar siswa kelas IV sebanyak 30 orang yang belum maksimal memenuhi tuntutan Kriteria Ketuntasan Minimal (KKM) yang telah ditetapkan dengan angka 70. Untuk lebih jelasnya disajikan pada tabel berikut.

Tabel 1. Hasil Belajar IPA Siswa

\begin{tabular}{|c|c|c|c|}
\hline KKM & Nilai & $\begin{array}{c}\text { Banyak } \\
\text { siswa }\end{array}$ & Presentase \\
\hline 70 & $\geq 70$ & 20 & 66,67 \\
\hline & $<70$ & 10 & 33,33 \\
\hline Jumlah & 30 & 100 \\
\hline
\end{tabular}

Tabel 1 menunjukkan bahwa jumlah siswa sebanyak 30 orang, ada 20 yang mendapat nilai di bawa KKM dengan persentase sebanyak (66,66\%), sedangkan 10 orang yang mendapat nilai diatas KKM dengan persentase sebanyak (33,33\%). Faktor penyebabnya, yaitu pembelajaran IPA di kelas IV Negeri 173229 Parinsoran Kecamatan Garoga masih didominasi oleh guru, dimana guru cenderung menyampaikan materi dan pemberian tugas. Sehingga semangat siswa untuk belajara IPA menjadi menurun, dan membuat siswa kurang tertarik pelajaran IPA.

Pembelajaran IPA sukar dipahami bila diajarkan dengan menyampaikan materi dan pemberian tugas saja, dan sarana prasarana juga kurang maka seorang guru harus dapat memilih dan menggunakan metode pembelajaran yang tepat dan sesuai untuk meningkatkan semangat belajar siswa, sehingga dapat meningkatkan hasil belajarnya. Dengan demikian peneliti memberi solusi untuk menerapkan metode demonstrasi pada proses pembelajaran. Haryono (2013:72) menyatakan bahwa "Metode demonstrasi merupakan suatu cara mengajar dengan memperagakan dan mempertunjukkan suatu proses, situasi, atau benda tertentu yang sedang dipelajari baik dalam bentuk sebenarnya maupun dalam bentuk tiruan yang dipertunjukkan oleh guru atau sumber belajar lain di depan seluruh siswa".

Pada metode demonstrasi diperlihatkan proses kejadian atau cara kerja suatu alat kepada peserta didik. Peragaan suatu proses dapat dilakukan oleh guru sendiri, dibantu beberapa peserta didik, dengan menggunakan metode demonstrasi pada proses pembelajaran dapat memberi variasi belajar yang menarik dan berkesan kepada siswa, sehingga diharapkan mampu meningkatkan semangat siswa untuk belajar serta meningkatkan hasil belajarnya.

Dari latar belakang masalah tersebut, maka penulis ingin melakukan penelitian tindakan kelas dirumuskan dengan judul Meningkatkan Hasil Belajar Siswa dengan Metode Demonstrasi.

\section{METODE PENELITIAN}

Jenis penelitian yang dilakukan penelitian tindakan kelas (PTK) dengan tujuan untuk memperbaiki pelaksanaan pembelajaran dan meningkatkan hasil belajar siswa dengan menggunakan Metode Demonstrasi pada mata pelajaran IPA. Sesuai dengan jenis penelitian 
yaitu penelitian tindakan kelas, maka desain penelitian dilakukan dengan empat tahapan. Arikunto, dkk (2015: 41) menyatakan bahwa "Model penelitian tindakan kelas terdapat empat tahapan, yaitu: Perencanaan, pelaksanaan, pengamatan, refleksi”. Refleksi awal dan observasi untuk mengidentifikasi masalah yang terjadi di dalam kelas. Peneliti dibantu guru kelas dalam mengidentifikasi masalah pembelajaran untuk meningkatkan hasil belajar siswa yang diharapkan dengan menggunakan model demonstrasi.

Teknik yang digunakan dalam pengumpulan data pada peneliti ini adalah lembar observasi dan tes.

\section{Lembar Observasi}

Observasi sebagai teknik pengumpulan data dengan penggunaan metode demonstrasi dalam meningkatkan hasil belajar, tahap bersamaan dilakukan dengan saat tindakan dilakukan. Observasi dilakukan observer untuk mengamati pelaksanaan pembelajaran yang meliputi aktivitas guru dan aktivitas siswa

\section{Test}

Alat pengumpulan data dalam penelitian ini adalah tes berbentuk essay test sebanyak empat soal, yang dibatasi pada jenjang kognitif C1 sebanyak dua soal dan jenjang kognitif C2 sebanyak tiga soal.

\section{1) Hasil Pelaksanaan Pembelajaran}

Untuk mencari perhitungan nilai akhir lembar observasi adalah sebagai berikut:

\section{a. Penilaian Aktivitas Guru}

Untuk mengetahui proses pelaksanaan pembelajaran aktivitas guru digunakan rumus:

$$
\mathrm{HP}=\frac{\text { Jumlah Hasil Observasi }}{\text { Jumlah Butir Pengamatan }}
$$

Tabel 2. Kriteria Aktivitas Guru

\begin{tabular}{|c|c|}
\hline Kriteria Penilaian & Keterangan \\
\hline $\mathrm{A}=81-100 \%$ & Baik Sekali \\
\hline $\mathrm{B}=61-80 \%$ & Baik \\
\hline $\mathrm{C}=41-60 \%$ & Cukup \\
\hline $\mathrm{D}=21-40 \%$ & Kurang \\
\hline $\mathrm{E}=0-20 \%$ & Sangat Kurang \\
\hline
\end{tabular}

(Piet A. Sahertian 2013: 60)

b. Penilaian Aktivitas Siswa
Untuk mengetahui proses pelaksanaan pembelajaran aktivitas siswa digunakan Rumus:

$$
\text { Nilai Siswa }=\frac{\text { Skor Perolehan }}{\text { Skor Maksimal }} \times 100 \%
$$

Asep Jihad (2013:131) menyatakan skala kriteria penilaian siswa yang digunakan adalah sebagai berikut:

Tabel 3. Kriteria Aktivitas Siswa

\begin{tabular}{|c|c|}
\hline Nilai & Keterangan \\
\hline $1=10-29$ & Sangat Kurang \\
\hline $2=30-49$ & Kurang \\
\hline $3=50-69$ & Cukup \\
\hline $4=70-89$ & Baik \\
\hline $5=90-100$ & Sangat Baik \\
\hline
\end{tabular}

\section{2) Ketuntasan Belajar Siwa}

Hasil belajar siswa dapat dilihat dari ketuntasan belajar siswa secara individual dan klasikal. Untuk mengetahui presentasi ketuntasan belajar siswa diuraikan sebagai berikut:

a. Ketuntasan Belajar Individual

Untuk mengatahui presentase kemampuan siswa secara individual dari setiap tes yang diberikan, maka peneliti menggunakan rumus ketuntsan hasil belajar (KB) sebagai berikut:

$$
\mathrm{KB}=\frac{\mathrm{T}}{\mathrm{Tt}} \times 100 \%
$$

(Trianto 2015: 241)

Keterangan:

$\mathrm{KB}=$ Ketuntasan belajar

$\mathrm{T}=$ Jumlah skor yang diperoleh siswa

$\mathrm{Tt}=$ jumlah skor total

Apabila siswa sudah mencapai nilai KKM (Kriteria Ketuntasan Minimal) yang sudah ditetepkan oleh sekolah, maka siswa tersebut dikatakan tuntas dalam belajar.

b. Ketuntasan Belajar Klasikal

Untuk menghitung presentase ketuntasan belajar secara klasikal digunakan rumus sebagai berikut:

$$
P=\frac{\text { Ssiswa yang tuntas belajar }}{\text { Esiswa }} \times 100 \%
$$

c. Rata-rata Hasil Belajar Siswa 
Untuk menghitung nilai rata-rata hasil belajar siswa dikelas digunakan rumus sebagai berikut:

$$
\bar{x}=\frac{\sum \mathrm{f}_{\mathrm{i}} \mathrm{x}_{\mathrm{i}}}{\sum \mathrm{f}_{\mathrm{i}}} \quad \text { Sudjana 2016:70) }
$$

Keterangan :

$\overline{\mathrm{x}}=$ rata-rata

$f_{i}=$ frekunsi yang sesuai dengan tanda-tanda xi $x_{i}=$ tanda kelas interval

\section{HASIL PENELITIAN DAN PEMBAHASAN} Deskripsi Hasil Penelitian

1. Data Hasil Penelitian Nilai Rata-rata Belajar Siswa Siklus I

Dari hasil ketuntasan individu dan klasikal maka dapat diperoleh nilai rata-rata dengan menggunakan tebel distribusi frekuensi pada tabel 4 sebagai berikut:

Tabel 4. Distribusi Frekuensi Nilai IPA Kelas IV

\begin{tabular}{|c|c|c|c|c|}
\hline No & Nilai & $f_{i}$ & $x_{i}$ & $f_{i} . X_{i}$ \\
\hline 1 & $50-55$ & 2 & 52,5 & 105 \\
\hline 2 & $56-61$ & 2 & 58,5 & 117 \\
\hline 3 & $62-67$ & 3 & 64,5 & 193,5 \\
\hline 4 & $69-73$ & 9 & 70,5 & 634,5 \\
\hline 5 & $74-79$ & 6 & 76,5 & 459 \\
\hline 6 & $80-85$ & 2 & 82,5 & 165 \\
\hline & & 24 & & 1674 \\
\hline
\end{tabular}

Nilai rata-rata kelas dengan menggunakan metode demonstrasi pada Siklus I adalah 69,75.

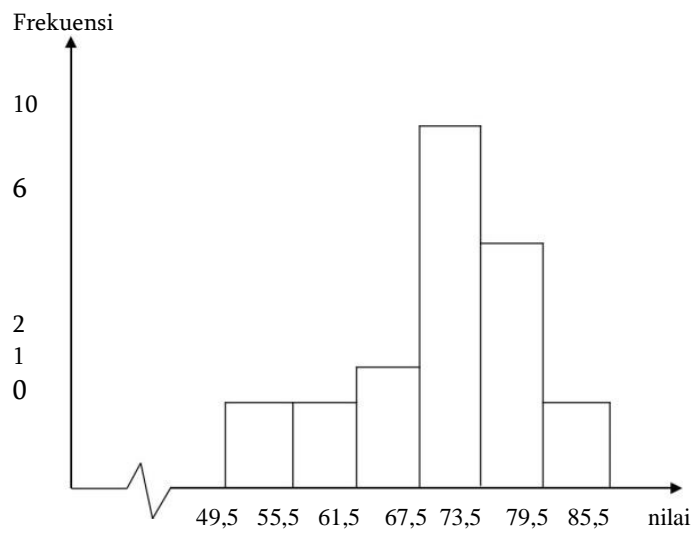

Gambar 1. Histogram Nilai Belajar IPA Siklus I

\section{Data Hasil Penelitian Nilai Rata-rata Belajar Siswa Siklus II}

Setelah dirangkum hasil ketuntasan belajar siswa secara individu dan klasikal maka selanjutnya data tersebut dicari nilai rata-ratanya. Hal tersebut diperoleh dari tabel data frekuensi sebagai berikut:

Tabel 5. Distribusi Frekuensi Nilai IPA Kelas IV

\begin{tabular}{|c|c|c|c|c|}
\hline No & Nilai & $f_{i}$ & $X_{i}$ & $f_{i} \cdot X_{i}$ \\
\hline 1 & $50-56$ & 1 & 53 & 53 \\
2 & $57-63$ & 1 & 60 & 60 \\
3 & $64-70$ & 1 & 67 & 67 \\
4 & $71-77$ & 10 & 74 & 740 \\
5 & $78-84$ & 7 & 81 & 567 \\
6 & $85-91$ & 4 & 88 & 352 \\
\hline & & 24 & & 1839 \\
\hline
\end{tabular}

Pada Siklus II diperoleh rata-rata hasil belajar siswa mengalami peningkatan yaitu 76,625. Frekuensi nilai hasil belajar siswa disajikan melalui histogram berikut:

Frekuensi

10

8

2 0

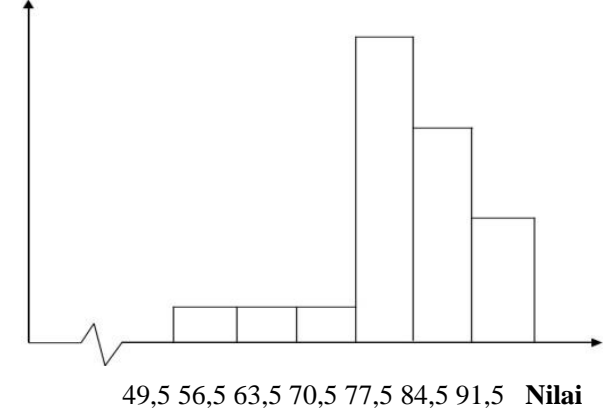

Gambar 2. Histogram Nilai Belajar IPA Siklus II

3. Perbandingan Data Hasil Penelitian Siklus I dan Siklus II

1. Perbandingan Data Hasil Penelitian Aktivitas Guru

Hasil pelaksanaan pembelajaran yang dilakukan oleh peneliti berdasarkan lembar observasi oleh observer pada Siklus I dan Siklus II sebagai berikut: 
Tabel 6 menunjukkan bahwa hasil pelaksanaan pembelajaran yang dilakukan oleh peneliti meningkat yaitu Siklus I diperoleh nilai

Tabel 7. Hasil Pelaksanaan Pembelajaran Aktivitas Siswa Siklus I dan Siklus II $60 \%$ dalam kategori cukup dan pada Siklus II diperoleh nilai 70,1\% dalam kategori baik.

Tabel 6. Hasil Pelaksanaan Pembelajaran Aktivitas Guru Siklus I dan Siklus II

\begin{tabular}{|c|c|c|c|}
\hline \multicolumn{2}{|c|}{ Peningkatan } & hasil & pelaksan \\
\hline \multirow[b]{2}{*}{ No } & \multicolumn{2}{|c|}{ Hasil Pengamatan } & \multirow[b]{2}{*}{ Ket } \\
\hline & Siklus I & Siklus II & \\
\hline 1 & 61 & 71 & Meningkat \\
\hline 2 & 62 & 72 & Meningkat \\
\hline 3 & 61 & 70 & Meningkat \\
\hline 4 & 55 & 64 & Meningkat \\
\hline 5 & 58 & 70 & Meningkat \\
\hline 6 & 60 & 68 & Meningkat \\
\hline 7 & 61 & 73 & Meningkat \\
\hline 8 & 61 & 70 & Meningkat \\
\hline 9 & 60 & 72 & Meningkat \\
\hline 10 & 61 & 71 & Meningkat \\
\hline Nilai & $60 \%$ & $70,1 \%$ & \\
\hline Kategori & Cukup & Baik & \\
\hline
\end{tabular}

\begin{tabular}{|c|c|c|c|}
\hline \multirow[b]{2}{*}{ No } & \multicolumn{2}{|c|}{ Hasil Pengamatan } & \multirow[b]{2}{*}{ Ket } \\
\hline & Siklus I & Siklus II & \\
\hline 1 & 3 & 4 & Meningkat \\
\hline 2 & 2 & 4 & Meningkat \\
\hline 3 & 4 & 5 & Meningkat \\
\hline 4 & 4 & 4 & Meningkat \\
\hline 5 & 4 & 4 & Meningkat \\
\hline 6 & 4 & 5 & Meningkat \\
\hline 7 & 4 & 4 & Meningkat \\
\hline 8 & 2 & 4 & Meningkat \\
\hline 9 & 2 & 4 & Meningkat \\
\hline 10 & 3 & 4 & Meningkat \\
\hline Nilai & 64 & 84 & \\
\hline Kategor & Cukup & Baik & \\
\hline
\end{tabular}

pembelajaran pada aktivitas guru dapat dilihat pada diagram berikut.

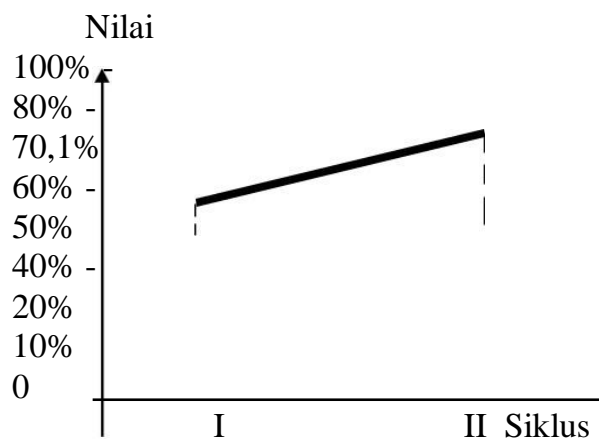

Gambar 3. Diagram Garis Hasil Observasi

Aktivitas Guru Siklus I dan Siklus II

Gambar 3 sesuai persentase peningkatan pelaksanaan pembelajaran pada aktivitas guru adalah $16,33 \% \%$.

\section{Perbandingan Data Hasil Penelitian Aktivitas Siswa}

Hasil pengamatan aktivitas siswa selama pembelajaran berlangsung pada Siklus I dan Siklus II sesuai pada Tabel 7.

an hasil pelaksanaan pembelajaran aktivitas siswa meningkat yaitu pada Siklus I diperoleh 64 dan pada Siklus II menjadi nilai 84. Peningkatan hasil pelaksanaan pembelajaran pada aktivitas siswa dapat disajikan pada diagram berikut.

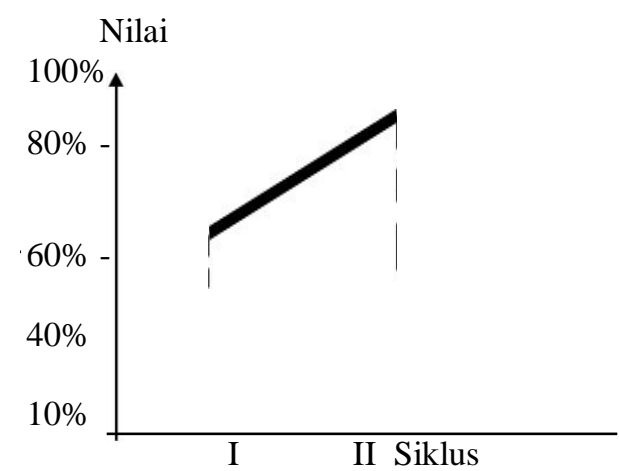

Gambar 4. Diagram Garis Hasil Observasi Aktivitas Siswa Siklus I dan Siklus II

Gambar 4 sesuai persentase peningkatan pelaksanaan pembelajaran pada aktivitas siswa adalah $31,25 \%$.

\section{Perbandingan Data Hasil Penelitian Secara Individual}


Pada Siklus I peningkatan hasil belajar siswa dari 24 jumlah siswa kelas IV terdapat 17 siswa yang tuntas belajar dengan persentase 70,33\%. Sedangkan pada Siklus II terdapat 21 siswa yang tuntas dengan persentase $87,50 \%$. Adapun peningkatan ketuntasan hasil belajar siswa dari Siklus I dan Siklus II disajikan pada gambar berikut.

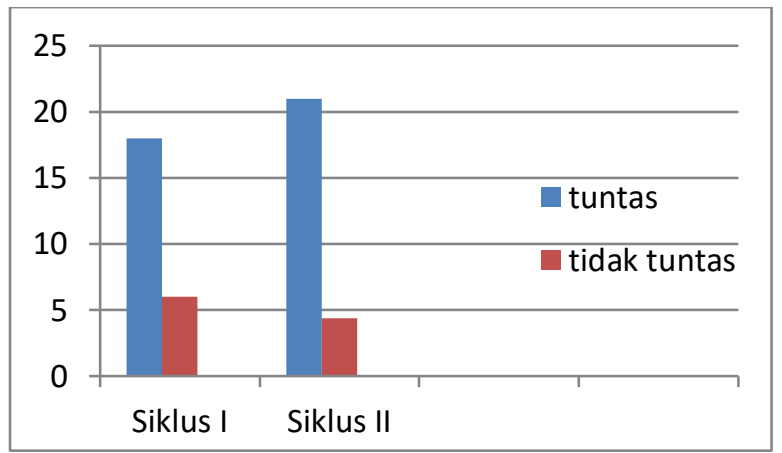

Gambar 5. Diagram Batang Perbandingan Nilai Belajar IPA Secara Individual

\section{Perbandingan Data Hasil Penelitian Secara klasikal}

Ketuntasan hasil belajar IPA siswa pada Siklus I dan Siklus II dapat disajikan pada Tabel 8 berikut :

Tabel 8. Perbandingan Hasil Belajar IPA Secara klasikal

\begin{tabular}{|c|l|c|c|c|}
\hline \multirow{2}{*}{ Siklus } & \multicolumn{3}{|c|}{ Siswa Tuntas } & \multicolumn{2}{l|}{ Siswa Tidak Tuntas } \\
\cline { 2 - 5 } & $f_{i}$ & Persentase (\%) & $f_{i}$ & Persentase (\%) \\
\hline I & 17 & 70,33 & 7 & 9,67 \\
\hline II & 21 & 87,50 & 3 & 2,50 \\
\hline
\end{tabular}

Tabel 8 jumlah siswa yang tuntas pada Siklus I sebanyak 17 orang (70,33\%) dan yang tidak tuntas belajarnya sebanyak 7 orang (29,67\%), sedangkan pada Siklus II jumlah siswa yang tuntas belajarnya meningkat menjadi 21 orang $(87,50 \%)$ dan jumlah siswa yang tidak tuntas belajarnya menurun menjadi 3 orang (12,50\%). Peningkatan hasil belajar siswa dapat digambarkan pada diagram garis berikut.

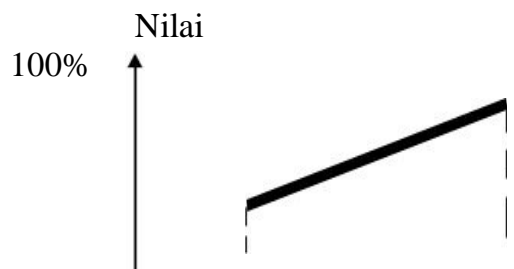

$80 \%-$

$70 \%$

$40 \%$

$10 \%$

$\begin{array}{ll}\mathrm{I} & \text { II Siklus } \\ (70,33 \%) & (87,50 \%)\end{array}$

Gambar 6. Diagram Garis Perbandingan

Ketuntasan Hasil Belajar Siswa Secara Klasikal

\section{Perbandingan Data Hasil Penelitian Nilai Rata-rata Belajar Siswa}

Nilai hasil belajar siswa pada Siklus I dan Siklus II diperoleh peningkatan nilai ratarata hasil belajar siswa. Penigkatan rata-rata nilai hasil belajar siswa pada Siklus I dan Siklus II, diuraikan pada tabel berikut:

Tabel 9. Perbandingan Nilai Rata-rata Hasil Belajar Siswa

\begin{tabular}{|c|c|}
\hline Siklus & Rata-rata \\
\hline I & 69,75 \\
\hline II & 76,625 \\
\hline
\end{tabular}

Tabel 9 menunjukkan rata-rata nilai hasil belajar siswa Siklus I adalah 69,75, sedangkan pada Siklus II rata-rata nilai hasil belajar siswa meningkat menjadi 76,625.

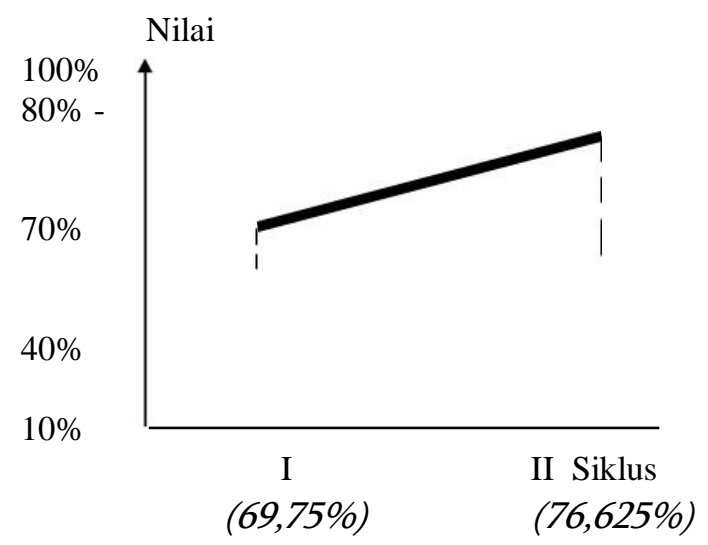

Gambar 7. Rata-Rata Hasil Belajar Siswa Pada Siklus I

Gambar 7 menunjukkan rata-rata hasil belajar siswa pada Siklus I adalah 69.75 meningkat sebesar 9,63\% menjadi 76,625 pada Siklus II.

6. Rekapitulasi Data Hasil Penelitian Siklus I dan Siklus II 
Rekapitulasi data hasil penelitian pada lembar observasi aktivitas guru, lembar observasi aktivitas siswa, ketuntasan belajar siswa secara individual dan klasikal, rata-rata hasil belajar siswa pada Siklus I dan Siklus II diuraikan pada Tabel 10 berikut.

Tabel 10. Rekapitulasi Data Hasil Penelitian Siklus I dan Siklus II

\begin{tabular}{|l|l|l|l|}
\hline $\begin{array}{r}\text { Data Hasil } \\
\text { Penelitian }\end{array}$ & Siklus I & Siklus II & Keterangan \\
\hline $\begin{array}{l}\text { Aktivitas } \\
\text { guru }\end{array}$ & $60 \%$ (cukup) & $70,1 \%$ (baik & $\begin{array}{l}\text { Meningkat } \\
(16,33 \%)\end{array}$ \\
\hline $\begin{array}{l}\text { Aktivitas } \\
\text { siswa }\end{array}$ & 64 (cukup) & 84 (baik) & $\begin{array}{l}\text { Meningkat } \\
(31,25 \%)\end{array}$ \\
\hline $\begin{array}{l}\text { Ketuntasan } \\
\text { individual } \\
\text { dan klasikal }\end{array}$ & $70,33 \%$ & $87,50 \%$ & $\begin{array}{l}\text { Meningkat } \\
(24,48 \%)\end{array}$ \\
\hline Rata-rata & 69,75 & 76,625 & $\begin{array}{l}\text { Meningkat } \\
(9,63 \%)\end{array}$ \\
\hline
\end{tabular}

Data dari Tabel 10 Siklus I dan Siklus II terjadi peningkatan, pada lembar observasi aktivitas guru Siklus I $60 \%$ meningkat sebesar $16,33 \%$ menjadi $70,1 \%$ Siklus II, lembar observasi aktivitas siswa Siklus I 64 meningkat sebesar $31,25 \%$ menjadi 84 Siklus II, ketuntasan belajar secara individual dan klasikal Siklus I 70,33\% meningkat sebesar $24,48 \%$ menjadi $87,50 \%$ Siklus II, rata-rata hasil belajar siswa siklus I 69,75 meningkat sebesar 9,63 menjadi 76,625 siklus II.

\section{PEMBAHASAN HASIL PENELITIAN}

Penelitian dilakukan di kelas IV SD Negeri 173229 Parinsoran Kecamatan Garoga T.A 2017/2018, hasil pelaksanaan penelitian pada Siklus I ternyata masih ada beberapa aspek yang harus diperbaiki sesuai lembar observasi yang di isi oleh pengamat. Pada lembar observasi guru yaitu belum dapat membimbing siswa dan memotivasi siswa saat pengelolaan kelas, belum dapat mengarahkan siswa untuk terlibat dalam pembelajaran sesuai dengan langkah-langkah metode demonstrasi sehingga guru belum dapat membimbing siswa pada pelaksanaan percobaan, dan belum dapat merangkum pelajaran dengan baik. Dan pada lembar observasi siswa yaitu siswa belum tepat waktu masuk ke dalam kelas, kurangnya kesiapan menerima pelajaran, dan menjawab pertanyaan dari guru, kurangnya ketertipan pada saat proses pembelajaran berlangsung sehingga kurang beraktivitas yang baik dalam mengerjakan soal tes, dari jumlah siswa sebanyak 24 siswa. Penelitian dilaksanakan dengan tujuan menigkatkan hasil belajar siswa dan menggunakan metode demonstrasi untuk membantu siswa dalam meningkatkan hasil belajar. Setelah dilakukanya penelitian Siklus I diperoleh data hasil observasi aktivitas guru dengan persentase $60 \%$ kategori cukup dan hasil observasi aktivitas siswa 64 kategori cukup. Pada hasil belajar siswa, diperoleh 17 siswa (70,33\%) yang dinyatakan tuntas dan 7 siswa $(29,67 \%)$ siswa dinyatakan tidak tuntas, sehingga rata-rata kelas yang diperoleh Siklus I adalah 69,75.

Dari data yang diperoleh pada Siklus I, dilakukan refleksi terhadap pembelajaran dan disimpulkan bahwa pembelajaran pada Siklus I belum maksimal. Terbukti dari hasil lembar obsevasi aktivitas guru dan siswa masih dalam kategori cukup. Hasil belajar siswa pada Siklus I juga belum dinyatakan maksimal, karena belum $85 \%$ siswa yang berada dalam kelas mencapai nilai KKM, sehingga belum dapat dikatakan tuntas secara klasikal.

Untuk memperbaiki pelaksanaan pembelajaran pada Siklus I peneliti melakukan perbaikan ke Siklus II. Pada pelaksanaan penelitian Siklus II, peneliti memperbaiki kekurangan-kekurangan pada pelaksanaan pembelajaran Siklus I. Pada lembar observasi aktivitas guru yaitu peneliti berusaha membimbing siswa untuk terlibat dalam pembelajaran dengan cara mengarahkan siswa agar betul-betul memperhatikan guru bagaimana proses pelaksanaan pembelajaran dengan baik menggunakan langkah-langkah metode demonstrasi, peneliti berusaha memotivasi siswa untuk tertip pada saat proses 
pembelajaran berlangsung, dan dapat merangkum pelajaran dengan baik. Dan pada lembar aktivitas siswa yaitu siswa masuk ke dalam kelas dengan tepat waktu, dan mempunyai kesiapan menerima pelajaran, adanya kesenangan dan kemampuan menjawab pertanyaan dari guru, bertambahnya ketenangan siswa pada saat proses belajar mengajar dan ketertipan pada saat mengerjakan soal tes Setelah dilakukan perbaikan pada Siklus II, diperoleh hasil penelitian pada lembar observasi aktivitas guru 70,1\% (baik), dan lembar aktivitas siswa 84 (baik). Dan dapat disimpulkan pelaksanaan pada pembelajaran Siklus II berkategori baik. Demikian pula dengan jumlah siswa yang tuntas hasil belajarnya sebanyak 31 siswa $(87,50 \%)$ sedangkan siswa yang belum tuntas sebanyak 3 siswa $(12,50 \%)$, hal ini sudah sesuai dengan kriteria ketuntasan klasikal.

Permasalahan pelaksanaan pembelajaran dan hasil belajar siswa dapat diatasi pada Siklus II, maka perbaikan pelaksanaan pembelajaran tidak perlu dilanjutkan pada Siklus berikutnya. Dan dapat disimpulkan pelaksanaan pembelajaran dengan menggunakan metode demonstrasi adalah baik, dan hasil belajar siswa meningkat setelah menggunakan Metode Demonstrasi.

\section{Simpulan}

\section{KESIMPULAN DAN SARAN}

Hasil penelitian tindakan kelas yang dilakukan oleh peneliti dapat disimpulkan bahwa:

1. Pelaksanaan pembelajaran IPA dengan menggunakan metode demonstrasi berkategori baik.

2. Hasil belajar siswa SD meningkat setelah menggunakan metode demonstrasi.

\section{Saran}

Saran peneliti adalah sebagai berikut sebagai berikut:

1. Diharapkan kepada guru agar dapat menggunakan metode demontrasi sebagai salah satu alternatif untuk memperbaiki dan meningkatkan hasil belajar siswa pada pelajaran IPA.

2. Diharapkan pada siswa agar dapat meningkatkan keaktifan siswa dalam proses pembelajaran dan menumbuhkan rasa sosial siswa melalui kerjasama yang baik dengan menerapkan metode demonstrasi.

\section{DAFTAR PUSTAKA}

Arikunto, Suharsimi, dkk. 2015. Penelitian Tindakan Kelas. Jakarta: Bumi Aksara.

Asep Jihad dan Abdul Haris. 2013. Evaluasi

Pembelajaran. Yogyakarta: Multi Pressindo.

Haryono. 2013. Pembelajaran IPA yang Menarik dan Mengasyikkan Teori dan Aplikasi PAIKEM. Yogyakarta: Kepel Press Putri Arsita A-6.

Piet A. Sahertian. 2013. Supervisi Pendidikan dalam Rangka Pengembangan Sumber Daya Manusia. Jakarta: Rineka Cipta

Sagala, 2012. Konsep dan Makna Pembelajaran. Bandung: Alfabeta CV.

Sudjana. 2016. Metode Statistika. Bandung: Tarsito.

Trianto. 2015. Model Pembelajaran Terpadu Konsep, Strategi, dan Implementasinya dalam Kurikulum Tingkat Satuan Pendidikan (KTSP). Jakarta: Bumi Aksara.

Zainal, Aqib,dkk. 2010. Penelitian Tindakan Kelas untuk Guru SD, SLB,TK. CV.Yrama Widya. 